\title{
Diagnosing abuse: a systematic review of torn frenum and other intra-oral injuries
}

\author{
Sabine Maguire, Bruce Hunter, Lindsay Hunter, Jo Richard Sibert, Mala Mann, Alison Mary Kemp, \\ for the Welsh Child Protection Systematic Review Group
}

See end of article for

Arch Dis Child 2007;92:1113-1117. doi: 10.1136/adc.2006.113001

authors' affiliations

Correspondence to:

Sabine Maguire,

Department of Child Health, Cardiff University, Cardiff,

UK; sabinemaguire@yahoo. co.uk

Accepted 21 April 2007

Published Online First

27 April 2007

Arch Dis Child 2007,92:1113-1117. doi: 10.1136/adc.2006.113001

Introduction: A torn labial frenum is widely regarded as pathognomonic of abuse.

Methods: We systematically reviewed the evidence for this, and to define other intra-oral injuries found in physical abuse. Nine studies documented abusive torn labial frena in 30 children and 27 were fatally abused: 22 were less than 5 years old. Only a direct blow to the face was substantiated as a mechanism of injury. Results: Two studies noted accidentally torn labial frena, both from intubation. Abusive intra-oral injuries were widely distributed to the lips, gums, tongue and palate and included fractures, intrusion and extraction of the dentition, bites and contusions.

Conclusions: Current literature does not support the diagnosis of abuse based on a torn labial frenum in isolation. The intra-oral hard and soft tissue should be examined in all suspected abuse cases, and a dental opinion sought where abnormalities are found.

$\mathrm{F}$ acial and intra-oral trauma has been described in up to $49 \%$ of infants and $38 \%$ of toddlers who have been physically abused. ${ }^{12}$ A torn labial frenum (often referred to as frenulum or phrenum) is widely believed by paediatricians to be pathognomonic of abuse, ${ }^{3}$ and has been described as the most common abusive injury to the mouth. ${ }^{45}$ Several abusive mechanisms have been proposed and include forced feeding, ${ }^{6}$ gagging, gripping and violent rubbing of, or a direct blow to, the upper lip. ${ }^{78} \mathrm{~A}$ torn labial frenum, however, is regarded as a trivial intra-oral injury by dental practitioners, as it is likely to heal spontaneously with minimal complications, and is not reported in large-scale dental trauma surveys. ${ }^{9}$

It is estimated that up to $50 \%$ of all school-age children sustain accidental dental injuries, ${ }^{10}$ challenging clinicians to distinguish between abusive and non-abusive injuries to the mouth.

We systematically reviewed the literature to establish the probability of a torn labial frenum being caused by physical child abuse and to define what other intra-oral injuries are found in physical abuse.

\section{METHODS}

Data sources and participants

We carried out an all-language literature search of research articles, conference abstracts, websites and references in all articles identified, including review articles and relevant textbooks from 1950 to June 2006. The key words and details of databases searched can be found in tables 1 and 2, respectively. Articles were scanned for duplication and relevance. Authors were contacted where necessary. The resulting studies were reviewed by members of the Welsh Child Protection Systematic Review Group, a panel of 31 people who were paediatricians, child health professionals with child protection expertise, or paediatric or forensic dentists. Each study was subjected to two independent reviews and a third if disputed. Standardised criteria for study definition, data extraction and critical appraisal were used. ${ }^{11}$ Full critical appraisal and data extraction forms are available at http://www.core-info.cf.ac.uk.

\section{Data extraction}

We included all studies of children aged 0-18 years with intraoral injuries due to physical child abuse, and torn labial frena of any aetiology, in live and fatal cases. We defined intra-oral as the area between the vermilion border of the lips and the hypopharynx.

We excluded review articles, expert opinion or guidelines that did not include primary evidence, studies with mixed adult and child data where the children's data could not be extracted, studies that addressed complications or management of abusive injuries, intra-oral injuries due to sexual abuse, or thermal injuries (as these will be encompassed in separate reviews) or dental neglect.

Studies were ranked by study design and by the likelihood that abuse had taken place in the "abused" population. We used our own ranking of abuse, as previously described, where a ranking of 1 gave the highest security of diagnosis that abuse had taken place, and a ranking of 5 the least confidence (table 3). ${ }^{12}$ We included studies with a ranking of $1-4$. In the case of non-abusive injuries, we only included studies where authors had described methods to ensure that abuse had been excluded.

\section{RESULTS}

Of 154 studies reviewed, 19 met the inclusion criteria. ${ }^{13-30}$ These represented data on 591 children. There were no comparative cross-sectional or case-control studies of torn labial frena to enable a probability of abuse to be determined for this injury. The only mechanism described for an abusive torn frenum was a direct blow to the face, recorded in two children. No details of mechanisms were given in other cases. Likewise, there were no comparative studies to compare the characteristics of other abusive and non-abusive intra-oral injuries.

\footnotetext{
Abusive torn labial frenum

Nine studies documented torn labial frena in abused children (table 4): seven were case series or case studies, ${ }^{14}$ 16-18 $202829^{2}$ and one was a case-control study. ${ }^{23}$ None of these studies were designed to address torn frena specifically; the case-control evaluated blunt abdominal trauma in association with cardiopulmonary resuscitation.

These studies represented data on 30 children, of whom 27 $(90 \%)$ were fatally abused. Twenty two were 5 years of age or
} 


\begin{tabular}{|c|c|}
\hline $\begin{array}{l}\text { Child abuse } \\
\text { child protection } \\
\text { (battered child or shaken baby } \\
\text { or battered baby) } \\
\text { child maltreatment } \\
\text { (child adj3 maltreatment) } \\
\text { (child adj3 physical abuse) } \\
\text { non-accidental injur: } \\
\text { soft tissue injur: } \\
\text { physical abuse. } \\
\text { physical punishment. } \\
\text { oral dental trau } \\
\text { oral facial injur:. } \\
\text { (oral or dental injur:) } \\
\text { (abrasion: or lesion: or laceration:). } \\
\text { (frenum or freanum or Frenulum). } \\
\text { (torn lingual or labial frenu:). } \\
\text { labial frenum/ } \\
\text { lingual frenum/ } \\
\text { (lingual frenum or freanum or } \\
\text { fraenum or phrenum). } \\
\text { (labial frenum or freanum). } \\
\text { ((torn adj3 labial frenum) or } \\
\text { freanum or frenulum). } \\
\text { phrenum } \\
\text { (torn lingual or labial frenum or } \\
\text { freanum or frenulum or phrenum). } \\
\text { alveol:: } \\
\text { avulsed teeth. }\end{array}$ & $\begin{array}{l}\text { avulsion injur:. } \\
\text { intraoral adj3 burn: } \\
\text { intraoral adj3 lesion: } \\
\text { lip scars. } \\
\text { lip or lips). } \\
\text { scars adj3 lip } \\
\text { vermilion border. } \\
\text { tongue.mp. } \\
\text { floor of mouth. } \\
\text { Luxation injury or luxated tooth } \\
\text { lateral luxation. } \\
\text { displaced tooth or intruded tooth or } \\
\text { extruded tooth or avulsed tooth } \\
\text { intrusion injury or extrusion injury } \\
\text { subluxated tooth } \\
\text { Crown fract: or root fract: } \\
\text { Crown adj3 fracture) or } \\
\text { root) adj3 fracture } \\
\text { Alveolar injury or alveolar fracture } \\
\text { dental traumatology. } \\
\text { oral traumatology. } \\
\text { Periodontal injury or gingival injury } \\
\text { gingivae or gingival laceration: } \\
\text { gingival contusion. } \\
\text { gingival tear } \\
\text { gingival bruise } \\
\text { torn fraenum or frenum } \\
\text { Occlusion or malocclusion } \\
\text { articulation or disarticulation }\end{array}$ \\
\hline
\end{tabular}

younger. The age range given was $0-10$ years for five children in one study. ${ }^{23}$ Four of these studies ranked 1 for abuse, three ranked 3 and two ranked 4 .

Cameron was the first to report a torn labial frenum as a consequence of physical abuse in 1966. ${ }^{14}$ In a retrospective study of 29 fatally abused children between birth and 4.5 years, he noted "the presence in nearly half of the cases of laceration of the mucosa of the inner aspect of the upper lip near the phrenum [sic], sometimes with tearing of the lip from the alveolar margin of the gum was a striking feature of possible significance" ${ }^{\prime 14}$ Later the same year, Tate ${ }^{29}$ reported six cases with abusive facial injury, three of whom had a torn frenum. The mechanism was described as a direct blow in two cases: a 2.5-year-old child with a torn frenum of the upper and lower lips was shaken and her head struck against a fireplace several times, and a 23-month-old child with a torn upper labial
Table 3 Ranking of the definitions of child abuse

\begin{tabular}{ll}
\hline Ranking & Criteria used to define abuse \\
\hline 1 & $\begin{array}{l}\text { Abuse confirmed at case conference or civil or criminal court } \\
\text { proceedings or admitted by perpetrator } \\
\text { Abuse confirmed by stated criteria including multi-disciplinary }\end{array}$ \\
2 & $\begin{array}{l}\text { assessment } \\
\text { Diagnosis of abuse defined by stated criteria }\end{array}$ \\
4 & $\begin{array}{l}\text { Abuse stated as occurring, but no supporting detail given as to } \\
\text { how it was determined }\end{array}$ \\
5 & $\begin{array}{l}\text { Abuse stated simply as "suspected", no details on whether it was } \\
\text { confirmed or not }\end{array}$ \\
\hline
\end{tabular}

frenum was struck about the face. Two of the three children were fatally abused with associated head injuries; multiple bruises and fractures were found in all three.

Of the remaining 11 reported cases, nine were fatally abused with associated head injury ${ }^{162830}$ (personal correspondence with authors), five had fatal abdominal injuries and one had co-existent ano-genital sexual abuse with multiple fractures. ${ }^{18}$ The remaining two had other intra-oral injuries, and one later sustained an intracranial injury. ${ }^{17} 20$

\section{Non-abusive torn labial frenum}

Two separate case studies documented a torn upper labial frenum occurring as a consequence of an intubation, both in fatally injured children. ${ }^{22}{ }^{23}$ No further details were offered. When contacted, the authors of the larger series of dental trauma in children ${ }^{21}$ replied that they did not record a torn frenum as they regarded this as a trivial dental injury.

\section{Abusive intra-oral injuries}

Fourteen studies documented other types of abusive intra-oral injuries. ${ }^{1}{ }^{13} 15^{17} 19-2124-30$ They were all case series or studies, and $11 / 14$ had a higher abuse ranking of 1 or 2 . They represented data on 579 children (table 5 ). The most commonly recorded abusive injuries to the mouth were lacerations or bruising to the lips. The remaining injuries included mucosal lacerations, dental trauma (including fractures, intrusion and forced extraction), tongue injuries and gingival lesions. No characteristics of these lesions were specific to an abusive aetiology, apart from an adult bite to a child's tongue. ${ }^{19}$

Becker recorded orofacial trauma in $49 \%$ of 260 abused children, $14(6 \%)$ of whom had intra-oral injuries. ${ }^{1}$ The largest series, by Naidoo, showed that $59 \%$ of 300 physically abused

Table 2 Databases used for the search strategy

\begin{tabular}{|c|c|}
\hline Database & Information \\
\hline ASSIA 1987-June 2006 & $\begin{array}{l}\text { ASSIA: Applied Social Sciences Index and Abstracts on the Web is an indexing and abstracting tool covering health, } \\
\text { social services, economics, politics, race relations and education }\end{array}$ \\
\hline CareData 1980-June 2006 & Social work and social care knowledge base \\
\hline ChildData 1958-June 2006 & National Children's Bureau database \\
\hline CINAHL 1982-June 2006 & $\begin{array}{l}\text { The Cumulative Index to Nursing and Allied Health (CINAHL) database provides authoritative coverage of the } \\
\text { literature related to nursing and allied health }\end{array}$ \\
\hline EMBASE 1980-June 2006 & $\begin{array}{l}\text { The EMBASE family consists of three separate databases: (1) EMBASE: Excerpta Medica Database, and its subsets, (2) } \\
\text { EMBASE Drugs and Pharmacology, and (3) EMBASE Psychiatry }\end{array}$ \\
\hline MEDLINE 1950-June 2006 & $\begin{array}{l}\text { Biomedicine, allied health, biological and physical sciences, humanities and information science as they relate to } \\
\text { medicine and health care, communication disorders, population biology and reproductive biology }\end{array}$ \\
\hline Ovid MEDLINE June 2006 & In-process and other non-indexed citations \\
\hline SIGLE 1980-June 2006 & $\begin{array}{l}\text { System for Information on Grey Literature in Europe is a bibliographic database covering European non-conventional } \\
\text { (so-called grey) literature in the fields of pure and applied natural sciences and technology, economics, social sciences } \\
\text { and humanities }\end{array}$ \\
\hline TRIP Database 1997-June 2006 & $\begin{array}{l}\text { The TRIP Database searches over } 55 \text { sites of high-quality medical information. It gives direct, hyperlinked access to the } \\
\text { largest collection of "evidence-based" material on the web as well as articles from premier on-line journals }\end{array}$ \\
\hline $\begin{array}{l}\text { Sciences Citation Index 1981-June } 2006 \\
\text { ISI Proceedings 1990-June 2006 }\end{array}$ & $\begin{array}{l}\text { Sciences Citation Index is a multidisciplinary database, covering the journal literature of the social sciences } \\
\text { Covers conference papers in all scientific and technical fields }\end{array}$ \\
\hline
\end{tabular}


Table 4 Studies of abusive torn frena

\begin{tabular}{|c|c|c|c|c|}
\hline Author/year & $\begin{array}{l}\text { Abuse ranking } \\
(1-5)\end{array}$ & $\begin{array}{l}\text { Number of } \\
\text { children (ages) }\end{array}$ & Co-existing injuries & Fatal/live \\
\hline Cameron et al, $1966^{14}$ & 3 & 13 approx (0-4.5 years) & Some tearing of the upper lip, near the frenum & All fatal \\
\hline Tate, $1971^{29}$ & 1,4 & 3 (23 months -4 years) & With/without intracranial injury & 1 live, 2 fatal \\
\hline Grace and Grace, $1987^{17}$ & 1 & 1 (18 months) & $\begin{array}{l}\text { Later readmitted - multiple fractures, intracranial injury, } \\
\text { pharyngeal puncture }\end{array}$ & Live \\
\hline Symons et al, $1987^{28}$ & 4 & 1 (3 years) & Contusion of eye/subdural haemorrhage, multiple bruises & Fatal \\
\hline Manning et al, $1990^{20}$ & 3 & 1 (4 months) & $\begin{array}{l}\text { Lacerations to uvula, upper gum, hard palate, floor of mouth. } \\
\text { Later retropharyngeal abscess }\end{array}$ & Live \\
\hline Hobbs and Wynne, $1990^{18}$ & 1 & 1 (0.4 years) & $\begin{array}{l}\text { Multiple bruises, sexual abuse, fractures and retinal } \\
\text { haemorrhages, developmental delay }\end{array}$ & Fatal \\
\hline Price et al, $2000^{23}$ & 1 & 5 (0-10 years) & $\begin{array}{l}\text { Extensive abdominal injuries, other injuries not detailed } \\
\text { in these cases }\end{array}$ & All fatal \\
\hline Cordner et al $2001^{16}$ & 1 & 1 (18 months) & $\begin{array}{l}\text { Occipital skull fracture, intracranial haemorrhage, } \\
\text { widespread bruising }\end{array}$ & Fatal \\
\hline $\begin{array}{l}\text { Phillips and van } \\
\text { der Heyde, } 2006^{30}\end{array}$ & 3 & 1 (5 years) & $\begin{array}{l}\text { Tramline bruising to legs, also bruising to eyes, ear and scalp. } \\
\text { Cerebral oedema }\end{array}$ & Fatal \\
\hline
\end{tabular}

children had facial injuries, $11 \%$ of whom had intra-oral injuries. ${ }^{21}$ The most common injuries recorded were to the lips (22 children). There were also seven fractured mandibles, and six injuries to oral mucosa, five to teeth, five to gingiva and three to the tongue. Torn frena were not recorded specifically. The children were selected from those with known physical abuse and orofacial injury. No child was examined by a dentist in any of these studies, and the data were collected retrospectively from chart reviews, raising the question of how often the mouth was actually examined.

Injuries to the tongue included an adult bite to an infant's tongue in a 10-month-old child, with the arc of the bite pointing towards the lips, confirming it could not have been self inflicted, with multiple fractures, bruises and subdural haemorrhages ${ }^{19}$ and abrasions and bruising.

In three studies oral bleeding was a presenting symptom. ${ }^{202627}$ In one case the infant re-presented five times from the age of 4 months, ${ }^{20}$ and was found to have a laceration of the uvula with several abrasions and lacerations of the upper gum, hard palate, floor of mouth and lingual frenum; the child developed a retropharyngeal abscess.

Injuries to teeth included displacement, chips, avulsions, intrusion and fractures. ${ }^{12124252930}$ One bizarre case series included three siblings who had endured forced dental extraction of permanent incisors as a form of punishment. ${ }^{15}$

\section{DISCUSSION}

This study confirms that intra-oral injury occurs in a significant number of children who have been physically abused. Injuries are widely distributed to the lips, gums, tongue and palate and include fractures, intrusion and extraction of the dentition, bruising, lacerations and bites.

There is a paucity of published scientific literature about the torn labial frenum. There are no studies defining the incidence of torn labial frena in abuse and none that compare the injury in abused and non-abused children. It is impossible, therefore, to ascribe a probability of abuse for a torn labial frenum. Published studies are limited to 30 highly selected cases where a torn labial frenum is described in predominantly pre-school children who had suffered serious abuse, and where the majority of cases were fatal with extensive associated injuries. The only substantiated cause of an abusive torn labial frenum was a direct blow. There were no recorded cases of forced feeding, twisting or rubbing causing this injury. The literature includes mention of torn labial frena that were not abusive, and therefore a torn frenum in isolation cannot be described as pathognomonic of physical abuse. Clearly the finding of an unexplained torn labial frenum in a young child warrants full investigation, but the paucity of data in the literature and the highly selected nature of cases reported precludes defining an age band where concern would be highest. A diagnosis of physical abuse should not be based on a single injury in isolation, but arrived at in the context of the child's medical, social and developmental history and the explanation offered for the injury.

Some of the largest series in the literature 31 were not eligible for inclusion as they were only ranked 5 for abuse. They included cases of suspected abuse, with no separation of data on those cases where abuse was actually confirmed.

It is important when assessing a possible torn labial frenum to consider rarer congenital abnormalities of the labial frena such as midline diastema, ${ }^{33}{ }^{34}$ hypertrophic frenum in association with hypoplastic left heart syndrome, ${ }^{35}$ and multiple frena in other congenital heart syndromes such as Ellis-van Creveld or Pallister-Hall ${ }^{36}{ }^{37}$ as possible explanations of the abnormality.

The most frequently reported abusive injury to the mouth is not a torn labial frenum, as has been suggested, ${ }^{4}$ but injury to the lips. This assumes that the mouths of all abused children in the various series were fully examined. As these were retrospective studies of case notes, ${ }^{121}$ this is far from clear. None of the described abusive intra-oral injuries had any diagnostic

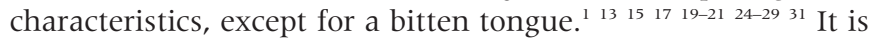
clear that paediatricians should always examine a child's mouth when assessing a child for suspected abuse. As it is doubtful whether non-dental specialists would recognise the significance of grey discolouration of the teeth as a microfracture or previous injury, ${ }^{38}$ or whether they would be able confidently to distinguish this from the characteristic yellowbrown to grey discoloration found in dentinogenesis imperfecta, it is important to involve dental colleagues. This would be particularly pertinent if co-existent skeletal fractures were found, as may be the case with combined osteogenesis imperfecta and dentinogenesis imperfecta. ${ }^{39}$ It is important that paediatricians are aware of the appropriate primary and secondary dentition expected at a given age, in order to question the absence of permanent teeth, as described by Carrotte. ${ }^{15}$

Many of the intra-oral injuries described in abused children are likely to be seen by general dental practitioners, yet dentists make very few child protection referrals. This is highlighted by Cotton, ${ }^{40}$ who noted that of 20000 child abuse investigations only 12 were initiated by dentists. A survey by Becker et al of 1332 dentists in the USA, where there was mandatory reporting with a response rate of $40 \%$, noted that 22 cases of child abuse were seen but only four (18\%) were referred to social services, ${ }^{1}$ 
Table 5 Abusive intra-oral injury

\begin{tabular}{|c|c|c|c|}
\hline Authors/year & Abuse rank & Number of children (age) & Orofacial injuries found \\
\hline Tate, $1971^{29}$ & 1 & 2 (23 months and 4 years) & $\begin{array}{l}\text { Case 1, chipped upper incisor, also torn frenum and fractures, killed } 3 \text { weeks later } \\
\text { Case } 2 \text {, severe laceration of upper lip and loose tooth. Multiple other soft tissue injuries }\end{array}$ \\
\hline Becker et al, 1978' & 4 & 260 (not given by authors) & $49 \%$ orofacial trauma, 14 intra-oral, 4 dental trauma, no other detail on location \\
\hline Swann and Glasgow, $1982^{27}$ & 2 & 1 (7 weeks) & $\begin{array}{l}\text { Oral bleeding, bruise and ulcer to fauces, abrasions and bruising to gingiva and } \\
\text { around tongue }\end{array}$ \\
\hline Schuman, $1987^{24}$ & 1 & 1 (10 years) & Midroot fracture of maxillary incisor \\
\hline Sobel, $1983^{25}$ & 1 & 1 (4 years) & $\begin{array}{l}\text { Facial abrasions/bruises, bruising of upper and lower lip, laceration of gingival and } \\
\text { alveolar mucosa, intrusion of one incisor and avulsion of incisor, fractured mandible }\end{array}$ \\
\hline Grace and Grace, $1987^{17}$ & 1 & 3 (10-18 months) & $\begin{array}{l}\text { Abrasions of hard palate with associated trauma to ear in one case, two cases of } \\
\text { laceration to pharyngeal wall, one with associated intracranial injury and one trauma } \\
\text { to ear }\end{array}$ \\
\hline Symons et al, $1987^{28}$ & 4 & 1 (3 years) & $\begin{array}{l}\text { Fatally abused, abrasion of upper lip, laceration of frenum of upper lip, intracranial } \\
\text { haemorrhage }\end{array}$ \\
\hline Manning et al, $1990^{20}$ & 1 & 1 (4 months) & $\begin{array}{l}\text { Recurrent oral bleeding, abrasions and lacerations of upper gum, hard palate, floor of } \\
\text { mouth and frenum. Retropharyngeal abscess }\end{array}$ \\
\hline Carrotte, $1990^{15}$ & 1 & $3(13$ years, $n / a)$ & Dental extraction of permanent teeth by parents as a punishment \\
\hline Barrett and Debelle, $1995^{13}$ & 2 & & Tear on posterior pharyngeal wall, forcible removal of an impacted dummy \\
\hline Naidoo, $2000^{21}$ & 2 & 300 ( 1 month- 14.25 years) & $\begin{array}{l}22 \text { lacerations to lips, } 6 \text { injuries to oral mucosa, } 5 \text { to teeth, } 5 \text { to gingiva, } 3 \text { to tongue. } \\
\text { Also unspecified number of loose or missing teeth. Seven fractures of mandible/ } \\
\text { maxilla }\end{array}$ \\
\hline Lee et al, $2002^{19}$ & 1 & 1 (10 months) & $\begin{array}{l}\text { Adult bite to the infants tongue, herpetic lesions perioral and intra-oral, also multiple } \\
\text { fractures, skin lesions and lacerations to ear and neck }\end{array}$ \\
\hline Stricker et al, $2002^{26}$ & 1 & 1 (9 days) & $\begin{array}{l}\text { Bleeding lesion on hard palate, discharged, returned at } 4 \text { weeks with multiple } \\
\text { fractures and intracranial haemorrhage }\end{array}$ \\
\hline $\begin{array}{l}\text { Phillips and van } \\
\text { der Heyde, } 2006^{30}\end{array}$ & 3 & $\begin{array}{l}4 \\
(20 \text { months, } 2.5 \text { years, } \\
3 \text { years, } 5 \text { years) }\end{array}$ & $\begin{array}{l}\text { Bruised lips, lacerated lips, bruised alveolar mucosa, avulsed teeth. All fatal cases, } \\
\text { co-existent lacerations, bruises, burns, fractures, sexual abuse (one case) and } \\
\text { scars to body, with fatal visceral and head injuries }\end{array}$ \\
\hline
\end{tabular}

despite a legal requirement to report suspected abuse. A similar study by Malecz ${ }^{41}$ showed that not only did few dentists report abuse cases, but $7 \%$ of 155 respondents said that under no circumstances would they report child abuse. Reasons cited included uncertainty about diagnosis and fear of litigation, although practitioners making a referral "in good faith" are protected from litigation in the United States. ${ }^{3}$ Even 12 years later, a survey of 250 dentists, 157 of whom responded, showed that $50 \%$ of dentists had suspected abuse but one third did not refer the case $^{42}$ and similar reluctance has recently been documented in the UK where $21 \%$ of dentists did not refer cases they suspected of having been abused. ${ }^{43}$ There have been a number of initiatives in the United States to tackle this issue ${ }^{44}{ }^{45}$ and Welbury et al have developed a computer-assisted learning programme for general dental practitioners in the United Kingdom, ${ }^{46}$ and the British Dental Council have recently published guidance. ${ }^{47}$

There is no legal mandatory reporting of child abuse in the UK, but the British Dental Association has made it clear that dentists do have an ethical responsibility to report child abuse. ${ }^{48}$ Clearly, those responsible for child protection training in each region must include dental practitioners and hygienists in such programmes, and offer ongoing support.

As in previous reviews, ${ }^{12}{ }^{49}$ children with disability were not represented. This is particularly disappointing as disabled children are recorded as being three times more likely to be abused than their able-bodied counterparts. ${ }^{50}$

Whilst this review did not deal with dental neglect, a notable number of cases presented co-existing neglect with resulting dental caries, likely to cause severe pain to the child. ${ }^{25}{ }^{28}$ Dental neglect while variably defined, ${ }^{38}$ should be considered in any child with extensive dental caries or early childhood caries where appropriate dental care has not been sought. ${ }^{51} 52$ This subject merits a review in its own right, in view of the potential implications in relation to pain, morbidity and faltering growth. ${ }^{53}$

Future research should be directed at determining the sensitivity and specificity of intra-oral injuries in abuse by well designed comparative studies. It is clear that we need to define those children who sustain accidental torn frena, in isolation or otherwise, by age, developmental stage and co-existent injury and cause, in order to aid the distinction from abusive torn frena. Attention should be given specifically to documenting the full extent of intra-oral injuries in physically abused children and their co-existent injuries, and this should include disabled children.

\section{ACKNOWLEDGEMENTS}

The authors wish to thank the following: NSPCC for their financial support of this systematic review; our reviewers: C Adams, M Barber, P Barnes, R Brooks, L Coles, P Davis, R Evans, L Hunter, R Frost, C Graham, M James-Ellison, B Hunter, R Jenkins, N John, A Kemp, K Kontas, H Lewis, A Maddocks, S Maguire, A Mott, A Naughton, C Norton, M Obaid, M Parry, H Payne, L Price, I Prosser, B Ellaway, J Sibert, E Webb, C Woolley; and Kim Rolfe for technical help with database management and editing of the paper.

\section{Authors' affiliations}

Sabine Maguire, Jo Richard Sibert, Alison Mary Kemp, Department of Child Health, Cardiff University, Cardiff, UK

Bruce Hunter, Lindsay Hunter, Dental School, University of Wales Hospital, Cardiff University, Cardiff, UK

Mala Mann, Support Unit for Research Evidence, Cardiff University, Cardiff, UK

Competing interests: None.

\section{REFERENCES}

1 Becker DB, Needleman HL, Kotelchuck M. Child abuse and dentistry: orofacial trauma and its recognition by dentists. J Am Dent Assoc 1978:97(1):24-8.

2 McMahon P, Grossman W, Gaffney M, et al. Soft-tissue injury as an indication of child abuse. J Bone Joint Surg Am 1995;77(8):1179-83.

3 Jessee SA. Detecting and reporting child maltreatment: dentists' obligations. Gen Dent 1994;42:218-21.

4 Benusis K. Child abuse: what the dentist should know. Northwest Dent 1977:56:260-3

5 Laskin DM. Editorial: the battered-child syndrome. J Oral Surg 1973;31(12):903.

6 McNeese MC. When to suspect child abuse. Am Fam Physician 1982;25(6):190-7. 
7 Anon. Dentists should be alert for child abuse evidence. J Am Dent Assoc 1979:99(1):116-17.

8 Macintyre DR, Jones GM, Pinckney RC. The role of the dental practitioner in the management of non-accidental injury to children. Br Dent $J$ 1986;161(3): 108-10

9 Gassner R, Vazquez Garcia J, Leja W, et al. Traumatic dental injuries and Alpine skiing. Endodont Dent Traumatol 2000;16:122-7.

10 Andreasen JO. Challenges in clinical dental traumatology. Endodont Dent Traumatol 1985; 1:45-55.

11 Centre for Reviews and Dissemination. Undertaking systematic reviews of research on effectiveness. CRD's guidance for those carrying out or commissioning reviews, CRD Report No.4, 2nd edn. York: University of York, 2001.

12 Maguire S, Mann MK, Sibert J, et al. Can you age bruises accurately in children? Arch Dis Child 2005:90:187-9.

13 Barrett TG, Debelle GD. Near-fatal aspiration of a child's dummy: design fault or deliberate injury? J Accid Emerg Med 1995;12:154-5.

14 Cameron JM, Johnson HRM, Camps FE. The battered child syndrome. Med Sci Law 1966;6:2-21.

15 Carrotte PV. An unusual case of child abuse. Br Dent J 1990;168(11):444-5.

16 Cordner SM, Burke MP, Dodd MJ, et al. Issues in child homicides: 11 cases. Legal Med 2001;3:95-103.

17 Grace A, Grace S. Child abuse within the ear, nose and throat. J Otolaryngol 1987;16(2): 108-11.

18 Hobbs CJ, Wynne JM. The sexually abused battered child. Arch Dis Child 1990;65:423-7.

19 Lee LY, Ilan J, Mulvey T. Human biting of children and oral manifestations of abuse. A case report and literature review. ASDC J Dent Child 2002;69(1):92-5.

20 Manning SC, Casselbrant M, Lammers M. Otolaryngologic manifestations of child abuse. Int J Pediatr Otorhinolaryngol 1990;20:7-16.

21 Naidoo S. A profile of the oro-facial injuries in child physical abuse at a children's hospital. Child Abuse Negl 2000;24:521-34.

22 Patel F. Artefact in forensic medicine: childhood iatrogenic oral injury. Police Surgeon 1992;41:8-9.

23 Price EA, Rush LR, Perper JA, et al. Cardiopulmonary resuscitation-related injuries and homicidal blunt trauma in children. Am J Forensic Med Pathol 2000;21(4):307-10.

24 Schuman NJ. Child abuse and the dental practitioner: discussion and case reports. Quintessence Int 1987;18(9):619-22.

25 Sobel RS, Kerns DL. A case of child abuse. In: Sanger RG, Bross DC, eds. Clinical management of child abuse. Chicago: Quintessence, 1983:159-64.

26 Stricker T, Lips U, Sennhauser FH. Oral bleeding: child abuse alert. J Paediatr Child Health 2002;38(5):528-9.

27 Swann A, Glasgow J. Child abuse - we must increase our level of suspicion. Ulster Med J 1982;51(2):115-20.

28 Symons A, Rowe PV, Romaniuk K. Dental aspects of child abuse: review and case reports. Aust Dent J 1987;32(1):42-7.

29 Tate RJ. Facial injuries associated with the battered child syndrome. Br J Oral Surg 1971;9(1):41-5.

30 Phillips VM, van der Heyde Y. Oro-facial trauma in child abuse fatalities. S Afr Med J 2006;96(3):A213-15.

31 Jessee SA. Physical manifestations of child abuse to the head, face and mouth: a hospital survey. ASDC J Dent Child 1995;62:245-9.
32 da Fonseca MA, Feigal RJ, ten Bensel RW. Dental aspects of 1,248 cases of child maltreatment on file at a major county hospital. Pediatr Dent 1992;14(3):152-7.

33 Chan L, Hodes D. Images in paediatrics. When is an abnormal frenulum a sign of child abuse? Arch Dis Child 2004;89:277.

34 Asahina I, Sakakibara T, Miyashin M, et al. Congenital midline sinus of the upper lip: case report and review of literature. Cleft Palate Craniofac J 1997;34(1):83-5.

35 Lovell MA, McDaniel NL. Association of hypertrophic maxillary frenulum with hypoplastic left heart syndrome. J Pediatr 1995;127(5):749-50.

36 lafolla K, Fratkin JD, Spiegel PK, et al. Case report and delineation of the congenital hypothalamic hamartoblastoma syndrome (Pallister-Hall syndrome). Am J Med Genet 1989:33:489-99.

37 da Silva E, Janovitz D, de Albuquerque SC. Ellis-van Creveld syndrome: report of 15 cases in an inbred kindred. J Med Genet 1980;17:349-56.

38 American Academy of Pediatrics. Oral and dental aspects of child abuse and neglect. Pediatrics 1999; 104(2):348-50.

39 Wright J, Thornton J. Osteogenesis imperfecta with dentinogenesis imperfecta. A mistaken case of child abuse. Pediatr Dent 1983;5:207-9.

40 Cotton EE. Steps in child protection: reporting, social services and the judicial system (part of a panel presentation). In: Proceedings: Dentists C.A.R.E. (Child Abuse Recognition and Education) Conference; 31 July to 1 August 1998, Chicago: American Dental Association, 1999:21-2.

41 Malecz RE. Child abuse, its relationship to pedodontics: a survey. ASDC J Dent Child 1979;46:193-4

42 Saxe MD, McCourt JW. Child abuse: a survey of ASDC members and a diagnostic-data-assessment for dentists. ASDC J Dent Child 1991;58(5):361-6.

43 Cairns AM, Mok JYQ, Welbury RR. The dental practitioner and child protection in Scotland. Br Dent J 2005; 198:517-20.

44 Herbert FL. A report on the first national conference on the "implications of child abuse and neglect for dental education and dental health care". ASDC J Dent Child 1981;48:311-12.

45 Kairys SW, Alexander RC, Block RW, et al. Oral and dental aspects of child abuse and neglect: joint statement of the American Academy of Pediatrics and the American Academy of Pediatric Dentistry. Pediatrics 1999;104(2):348-50.

46 Welbury R, Hobson R, Stephenson J, et al. Evaluation of a computer-assisted learning programme on the oro-facial signs of child physical abuse (nonaccidental injury) by general dental practitioners. Br Dent J 2001;190:668-70.

47 Harris J, Sidebotham P, Welbury R. Child protection and the dental team: an introduction to safeguarding children in dental practice. Sheffield: Committee of Postgraduate Dental Deans and Directors (COPDEND), 2006. Available at: http://www.cpdt.org.uk/f_info/dload/CPDHT.pdf (accessed 13 May 2007).

48 Welbury RR, Murphy JM. The dental practitioner's role in protecting children from abuse. 3 . Reporting and subsequent management of abuse. $\mathrm{Br}$ Dent $J$ 1998;184(32): 115-19.

49 Maguire SA, Kemp AM, Mann MM, et al. Are there patterns of bruising which are diagnostic or suggestive of abuse in children? A systematic review. Arch Dis Child 2003;88(Suppl 1):A3.

50 Sullivan PM, Knustson JF. Maltreatment and disabilities: a population based epidemiological study. Child Abuse Negl 2000;24(10): 1257-73.

51 Curzon M. Non-accidental injury (NAI). Eur J Paediatr Dent 2003;4(2):58.

52 Loochtan RM, Bross DC, Domoto PK. Dental neglect in children: definition, legal aspects, and challenges. Pediatr Dent 1986;8(1):113-16.

53 Blumberg ML, Kunken FR. The dentist's involvement with child abuse. NY State Dent J $1981 ; 47(2): 65-9$. 
Table 1 Single values and mean nNO levels of patients with PCD

\begin{tabular}{llll}
\hline Patient & T0 $\boldsymbol{p p b}$ & T1 $\boldsymbol{p p b}$ & T2 $\boldsymbol{p p b}$ \\
\hline Case 1 & $9.2 ; 6.5 ; 6.0$ mean 7.2 & $10 ; 8.0 ; 6.0$ mean 8.0 & $6.0 ; 10 ; 10$ mean 8.6 \\
Case 2 & $38 ; 42 ; 43$ mean 41 & $43 ; 35 ; 37$ mean 38.3 & $25 ; 40 ; 25$ mean 30
\end{tabular}

Case 1: T0 at 5 days of life, T1 at 30 days without clinical symptoms and finally T2 at 60 days of life.

Case 2: T0 first test, $\mathrm{T} 1$ after 60 days and $\mathrm{T} 2$ after 90 days.

$\mathrm{nNO}$, nasal nitric oxide; $\mathrm{PCD}$, primary ciliary dyskinesia.

Therefore, the levels of $\mathrm{nNO}$ in the elder brother and parents were evaluated. The $\mathrm{nNO}$ levels were normal in both parents. By contrast, in the 7-year-old child the mean $\mathrm{nNO}$ level was $41 \mathrm{ppb}$ at the first assessment, and it was confirmed as low (30 ppb) after 90 days, when he was in a stable healthy period. The PCD diagnosis in case 2 was also confirmed by nasal brushing, but in this case the imaging investigation failed to show situs viscerum inversus. For both brothers intensive physiotherapy was instituted.

PCD is an underdiagnosed genetic disease that represents a rare cause of neonatal respiratory distress. In half of the patients it is associated with situs viscerum inversus (Kartagener's syndrome), and some of these patients have mild minimal transmission electron microscopy defects (ie, atypical PCD), ${ }^{1}$ with a wide spectrum of disease variability.

Recent studies have demonstrated low $\mathrm{nNO}$ levels in patients with PCD compared with healthy age-matched subjects and, therefore, this measurement has been proposed as a diagnostic marker for screening. ${ }^{2}$ Our observation that markedly low levels of nNO represent a characteristic feature of PCD even in newborns with situs viscerum inversus and respiratory distress at birth ${ }^{5}$ further supports the use of this marker for the early detection of the disease in children.

To the best of our knowledge, the case we are reporting is the first demonstration of the potential application of $\mathrm{nNO}$ as a noninvasive, low-cost tool for the family screening of PCD after the identification of a positive case in a newborn.

\section{A Bodini, ${ }^{1}$ S Rugolotto, ${ }^{2}$ U Pradal, ${ }^{3}$ G Zanotto, ${ }^{4}$} D Peroni'

${ }^{1}$ Clinica Pediatrica, Università di Verona, Verona, Italy; ${ }^{2}$ U.0. Patologia e Terapia Intensiva Neonatale, Ospedale Policlinico G.B. Rossi, Verona, Italy; ${ }^{3}$ Centro Regionale Fibrosi Cistica, Ospedale Civile Maggiore, Verona, Italy; ${ }^{4}$ U.O. di Pediatria; Ospedale Sacro Cuore di Negrar, Verona, Italy

Correspondence to: Diego Peroni, Dipartimento di Pediatria, Policlinico G.B. Rossi, 37134 Verona, Italy; diego.peroni@tiscalinet.it

Acknowledgements: The authors thank the Valeas S.p.a. for providing the NIOX chemiluminescence analyser (Aerocrine, Stockolm, Sweden).

Competing interests: None declared.

Accepted 28 January 2008

Arch Dis Child 2008;93:452-453.

doi:10.1136/adc.2008.138636

\section{REFERENCES}

1. Bush A, Chodhari R, Collins N, et al. Primary ciliary dyskinesia: current state of the art. Arch Dis Child 2007;92:1136-40.
2. Wodehouse T, Kharitonov SA, Mackay IS, et al. Nasal nitric oxide measurements for the screening of primary ciliary dyskinesia. Eur Respir J 2003;21:43-7.

3. Struben VMD, Wieringa MH, Mantingh CJ, et al. Nasal NO: normal values in children age 6 through to 17 years. Eur Respir J 2005;26:453-7.

4. Piacentini GL, Bodini A, Peroni D, et al. Nasal nitric oxide for early diagnosis of primary ciliary dyskinesia: practical issues in children. Resp Med 2008;102:541-7.

5. Stehling $\mathbf{F}$, Roll $\mathrm{C}$, Ratjen $\mathrm{F}$, et al. Nasal nitric oxide to diagnose primary ciliary dyskinesia in newborns. Arch Dis Child Fetal Neonatal Ed 2006;91:F233-4.

6. Baraldi E, Pasquale MF, Cangiotti AM, et al. Nasal nitric oxide is low early in life: case study of two infants with primary ciliary dyskinesia. Eur Respir J 2004;24:881-3.

\section{Prevalence of anaemia in an inner city primary school population}

Iron deficiency, defined as a serum ferritin level of $<15 \mu \mathrm{g} / \mathrm{l}^{1}$ has been shown to adversely affect many aspects of health and development in childhood and persistence into school age may result in sub-optimal health and academic under-achievement. National research has demonstrated that a high prevalence of anaemia in pre-school children $(12 \%)$, causally linked to iron deficiency related to dietary factors, is common in areas of socioeconomic deprivation $^{1}$ and particularly in children of minority ethnic parentage, especially of Pakistani origin. ${ }^{2}$ There is little information in the literature about the prevalence of anaemia in school aged populations, so trained operators using a HaemoCue (HaemoCue, Ängelholm, Sweden) machine ${ }^{3}$ tested a whole school sample in an inner city area with a high percentage of children of Pakistani parentage.

A total of 319 children aged 4-11 years were tested, representing an uptake rate of $90 \% ; 88 \%$ of these children were of Pakistani origin. Anaemia was found in 25\% $(95 \% \mathrm{CI}$ $20 \%$ to $30 \%$ ) of the children: $22 \%$ ( $95 \% \mathrm{CI}$ $18 \%$ to $27 \%$ ) were mildly anaemic and $3 \%$ (95\% CI $1 \%$ to $5 \%$ ) were severely anaemic. We used the standard WHO reference ${ }^{4}$ for defining severe anaemia as a haemoglobin level below $9.0 \mathrm{~g} / \mathrm{dl}$ for those under 5 years of age and below $9.5 \mathrm{~g} / \mathrm{dl}$ for those 5 years of age and over. Mild anaemia was defined as a haemoglobin level between 9.0 and $10.9 \mathrm{~g} / \mathrm{dl}$ for those under 5 and between 9.5 and 11 . $4 \mathrm{~g} / \mathrm{dl}$ for those aged 5 and over. No significant trend across school years was found.

Parents or carers of the mildly anaemic children were offered dietary advice and follow-up by the community nursing team. The eight children who were severely anaemic were assessed by a community paediatrician and appropriate treatment and follow-up were arranged. Full blood count, serum electrophoresis and serum ferritin levels were carried out and confirmed iron deficiency in all eight cases. One child was found to have the thalassaemia trait in addition to iron deficiency.

We have demonstrated that anaemia is a significant health problem in this school aged population, most likely caused by iron deficiency. We are now carrying out similar studies in other local areas of different ethnicity and social constitution to ascertain whether this is a more general problem. It may be that the problem is related as much to the modern western diet of a school age child as to the continuing effects of traditional weaning and early childhood diets that have been implicated in this population. It will also be important to ascertain the extent of any problem in the adolescent age group.

\section{E A Adamson, G R Bailey, N Richards, H Wilson}

Children's Services, Derby City PCT, Derby, UK

Correspondence to: E A Adamson, Children's Services, Derby City PCT, Wilderslowe, 121 Osmaston Road, Derby DE1 2GA, UK; Liz.Adamson@derbycitypct.nhs.uk

Competing interests: None.

Arch Dis Child 2008;93:453. doi:10.1136/adc.2007.116301

\section{REFERENCES}

1. Gregory JR, Collins DL, Davies PSW, et al. National diet and nutrition survey. London: HMSO, 1995.

2. Ehrhardt $\mathbf{P}$. Iron deficiency in young Bradford children from different ethnic groups. BMJ 1986;292:90-3.

3. Mills AF, Meadows N. Screening for anaemia: evaluation of haemoglobinometer. Arch Dis Child 1989:64:1468-70.

4. World Health Organization. Iron deficiency anaemia. assessment, prevention and control. A guide for programme managers. Geneva: WHO, 2001.

\section{CORRECTION}

doi:10.1136/adc.2006.113001corr1

Maguire S, Hunter B, Hunter L, et al. Diagnosing abuse: a systematic review of torn frenum and other intra-oral injuries (Arch Dis Child 2007;92:1113-17).

A number of errors were published in this paper as follows:

In the methods section of the Abstract the second sentence should read: "Nine studies documented abusive torn labial frena in 27 children and 24 were fatally abused..."

The second sentence of the Results section should read: "These represented data on 603 children." Also in the Results section, under the subheading "Abusive torn labial frenum", first sentence of the second paragraph should read: "These studies represented data on 27 children, of whom 24 (88\%) were fatally abused."

Under the heading "Abusive intra-oral injuries" on $\mathrm{p} 1114$ the third sentence of the first paragraph should read: "They represented data on 580 children (table 5)." 
ADC

\section{Diagnosing abuse: a systematic review of torn frenum and other intra-oral injuries}

Sabine Maguire, Bruce Hunter, Lindsay Hunter, et al.

Arch Dis Child 2007 92: 1113-1117 originally published online April 27, 2007

doi: 10.1136/adc.2006.113001

Updated information and services can be found at:

http://adc.bmj.com/content/92/12/1113.full.html

These include:

References This article cites 49 articles, 8 of which can be accessed free at: http://adc.bmj.com/content/92/12/1113.full.html\#ref-list-1

Article cited in:

http://adc.bmj.com/content/92/12/1113.full.html\#related-urls

Email alerting Receive free email alerts when new articles cite this article. Sign up in service the box at the top right corner of the online article.

Topic Articles on similar topics can be found in the following collections Collections

Child abuse (149 articles)

Dentistry and oral medicine (71 articles)

Injury (173 articles)

Trauma (171 articles)

Abuse (child, partner, elder) (64 articles)

Notes

To request permissions go to:

http://group.bmj.com/group/rights-licensing/permissions

To order reprints go to:

http://journals.bmj.com/cgi/reprintform

To subscribe to BMJ go to:

http://group.bmj.com/subscribe/ 